\title{
Journal of Health Science
}

(Jurnal Ilmu Kesehatan)

https://www.ejournalwiraraja.com/index.php/JIK 2356-5284 (Print)|2356-5543 (online)

\section{Perbedaan Indeks Trombosit (PDW, MPV, P-LCR, PCT) dan Jumlah Trombosit Antara Pasien Infeksi Dengue Primer dan Sekunder Di RSUD Dr. H. Abdul Moeloek Provinsi Lampung}

\section{Hidayat ${ }^{1}$, Tusy Triwahyuni ${ }^{2}$, Zulfian ${ }^{3}$,Vita Lestari Ayuningsih ${ }^{4}$}

${ }^{1}$ Instalasi Laboratorium Patologi Klinik RSUD Dr. H. Abdul Moeloek Provinsi Lampung

${ }^{2}$ Departemen Parasitologi Fakultas Kedokteran Universitas Malahayati

${ }^{3}$ Departemen Patologi Klinik RS Pertamina Bintang Amin

${ }^{4}$ Program Studi Kedokteran Fakultas Kedokteran Universitas Malahayati

Vitalstr_03@yahoo.co.id*

*Corresponding author

\begin{tabular}{ll}
\hline Informasi artikel & \\
\hline Sejarah artikel: & \\
Received: $09-04-2021$ & \\
Revised: $08-06-2021$ & \\
Accepted:25-06-2021 \\
\hline Kata kunci:
\end{tabular}

ABSTRAK

Demam berdarah dengue termasuk penyakit endemik yang disebabkan oleh virus dengue. Manifestasi klinis ditandai oleh trombositopenia. Trombositopenia terjadi melalui mekanisme supresi sumsum tulang, destruksi dan pemendekan masa hidup trombosit. Selain jumlah trombosit, terdapat indeks trombosit yang diketahui sebagai aktivasi trombosit yaitu PDW, MPV, P-LCR dan PCT. Tujuan penelitian untuk mengetahui perbedaan indeks trombosit (PDW, MPV, P-LCR, PCT) dan jumlah trombosit pada pasien infeksi dengue primer dan sekunder di RSUD Dr. H. Abdul Moeloek Provinsi Lampung. Penelitian ini menggunakan metode analitik cross-sectional. Populasi yaitu pasien infeksi dengue primer dan sekunder menggunakan metode total sampling dengan jumlah sampel sebanyak 35 pasien. Data diperoleh dari rekam medis di RSUD Dr. H. Abdul Moeloek Provinsi Lampung. Analisis data dengan uji independent $\mathrm{T}$ test dan uji Mann Whitney. Dari 35 data didapatkan hasil yang terinfeksi dengue primer sebanyak 13 orang $(37,1 \%)$ dan 22 orang $(62,9 \%)$ terinfeksi dengue sekunder. Median PDW infeksi dengue primer $9,7 \pm 1,24 \%$ dan sekunder $10,75 \pm 1,87 \%$. Median MPV infeksi dengue primer 9,7 $\pm 2,25 \mathrm{fL}$ dan sekunder 10,087 $\pm 0,84 \mathrm{fL}$. Rerata P-LCR infeksi dengue primer 20,58 $\pm 7,93 \%$ dan sekunder $25,33 \pm 6,84 \%$. Median PCT infeksi dengue primer $0,17 \pm 1,07 \%$ dan sekunder $0,18 \pm 0,07 \%$. Rerata jumlah trombosit infeksi dengue primer $169.523,08 \pm 57.590,713 / \mu \mathrm{L}$ dan sekunder 179.318,18 $\pm 75.082,422 / \mu \mathrm{L}$. Hasil uji statistik didapatkan nilai $\mathrm{p}$; PDW nilai $\mathrm{p}=0,068$, MPV nilai $\mathrm{p}=0,538$, P-LCR nilai $\mathrm{p}=0,101$, PCT nilai $\mathrm{p}=0,973$ dan jumlah trombosit nilai $\mathrm{p}=0,393$. Tidak terdapat perbedaan bermakna antara indeks trombosit (PDW, MPV, P-LCR, PCT) dan jumlah trombosit untuk infeksi dengue primer dengan sekunder.

Key word:

Dengue Infection

Platelet

Platelet Index

\begin{abstract}
Dengue hemorrhagic fever is endemic disease caused by dengue virus. Clinical symptomp marked by trombositopenia. Trombositopenia occurs through in mechanism of bone marrow suppresion, destruction and shortening of platelet life span. Morever platelet count, there are platelet index who known as platelet activator are PDW, MPV, P-LCR and PCT. This research to determine the difference platelet index (PDW, MPV, P-LCR, PCT) and platelet count between primary and secondary dengue infection patient at Regional General Hospital Dr. H. Abdul Moeloek Lampung Province. The research use analytic observational method with cross-sectional research design. Population are patient who diagnosed with primary and secondary dengue infection and using total sampling method for sampling with 35 patient. Data obtained from Regional General Hospital Dr. H. Abdul Moeloek Lampung Province. Data were analyzed by independent T test and Mann Whitney test. Based on 35 data from medical records, the patient who diagnosed as primary dengue infection are 13 people $(37,1 \%)$ and 22 people $(62,9 \%)$ who diagnosed as secondary dengue infection. Median of PDW
\end{abstract}


primary dengue infection was $9,7 \pm 1,24 \%$ and secondary dengue infection was $10,75 \pm 1,87 \%$. Median of MPV primary dengue infection was 9,7 $\pm 2,25 f L$ and secondary dengue infection was 10,087 $\pm 0,84$ fL. Mean of P-LCR primary dengue infection was 20,58 $\pm 7,93 \%$ and secondary dengue infection was $25,33 \pm 6,84 \%$. Median of PCT primary dengue infection was $0,17 \pm 1,07 \%$ and secondary dengue infection was $0,18 \pm 0,07 \%$. Mean of platelet count primary dengue infection was 169.523,08 $\pm 57.590,713 / \mu \mathrm{L}$ and secondary dengue infection was 179.318,18 $\pm 75.082,422 / \mu L$. Based on the result of statistical analyisis data, PDW $p$ value $=0,068, M P V \quad p$ value $=0,538, P-L C R \quad p$ value $=0,101$, PCT $p$ value $=0,973$ and platelet count $p$ value $=0,393$. There are no significant differences platelet index (PDW, MPV, P-LCR, PCT) and platelet count in primary with secondary dengue infection.

\section{PENDAHULUAN}

Infeksi dengue merupakan penyakit demam akut dengan manifestasi klinis yang bervariasi meliputi demam dengue, demam berdarah dengue dan dengue syok sindrom (Utari et al., 2018). Infeksi dengue primer bermanifestasi lebih ringan dibandingkan infeksi dengue sekunder. Infeksi dengue di Indonesia memiliki 4 serotipe virus yaitu DENV-1, DENV-2, DENV-3, dan DENV-4. Keempat serotipe virus tersebut dapat menyebabkan demam dengue dan demam berdarah dengue. Serotipe DEN-3 merupakan serotipe virus terbanyak. Virus dengue termasuk dalam genus Flavivirus keluarga Flaviviridae (Suhendro et al., 2014).

Infeksi dengue merupakan masalah kesehatan yang terjadi di seluruh dunia dimana setiap tahun sekitar 390 juta orang. Tahun 2020 infeksi dengue telah dilaporkan terjadi peningkatan kasus di beberapa negara salah satunya yaitu Indonesia (WHO,2020). Kejadian infeksi dengue di Indonesia pada tahun 2020 mencapai 71 ribu kasus cenderung menurun dibandingkan tahun 2019 dimana mencapai 114 ribu kasus. Sekitar 10 provinsi yang telah melaporkan jumlah kasus infeksi dengue salah satu diantaranya yaitu provinsi Lampung. Di provinsi Lampung pada tahun 2020 terdapat sekitar 5 ribu kasus (Kemenkes RI, 2020). Sesuai dengan kriteria WHO (World Health Organization) pemeriksaan jumlah trombosit merupakan salah satu indikator yang digunakan untuk menegakkan diagnosis infeksi dengue (Noreka et al.,2020). Trombosit memiliki beberapa indeks yang dapat diketahui menggunakan alat hematology analyzer. Pemeriksaan ini terdiri dari PDW (Platelet Dstribution Width), MPV (Mean Platelet Volume), P-LCR (Platelet Large Cell Ratio) dan PCT (Plateletcrit) yang merupakan indikator aktivasi trombosit (Astuti,2020). PDW merupakan ukuran diameter trombosit yang berada di darah perifer.
Nilai normal PDW adalah 10-18 fl. Mean Platelet Volume (MPV) merupakan rata-rata jumlah trombosit yang beredar dalam darah perifer (Purba, 2017). Nilai normal MPV adalah 8,4-12 fL (Utami, 2017). Pada populasi sehat, PDW dan MPV berada dalam hubungan terbalik dengan jumlah trombosit (Syuhada et al., 2015). Platelet Large Cell Ratio (P-LCR) merupakan proporsi jumlah trombosit normal yang berukuran lebih sari 12 fL. Nilai normal PLCR adalah 10-30\% (Utami, 2017). Nilai P LCR berbanding terbalik dengan jumlah trombosit dan berhubungan langsung dengan MPV dan PDW. Apabila didapatkan rasio terbalik dari P-LCR menandakan fungsi trombosit tidak normal sehingga meningkatan resiko pendarahan (Babu dan Basu, 2004).

$$
\text { Plateletcrit (PCT) merupakan }
$$

parameter untuk mendeteksi proporsi volume seluruh darah yang ditempati oleh trombosit (Prameswari et al., 2018). Dalam keadaan normal nilai PCT adalah 0,22-0,24\% (Astuti, 2020). Nilai PCT dan jumlah trombosit akan rendah pada dengue parah dan akan mengalami peningkatan pada fase pemulihan. PCT akan meningkat bersamaan dengan penaikan jumlah trombosit pada hari ke-3 dan hari ke-7 (Chatterjeee et al,. 2020). Pada pasien dengue fever ditemukan nilai MPV, PCT, dan jumlah trombosit cenderung menurun. Namun pada DBD ditemukan nilai MPV cenderung meningkat meskipun dalam batas normal sedangkan nilai PCT dan jumlah trombositnya menurun (Prameswari et al., 2018). Tujuan dari penelitian ini adalah untuk mengetahui apakah terdapat perbedaan indeks trombosit (PDW, MPV, P-LCR, PCT) dan jumlah trombosit antara pasien infeksi dengue primer dan sekunder di RSUD Dr. H. Abdul Moeloek Provinsi Lampung. 


\section{METODE PENELITIAN}

Jenis penelitian ini merupakan jenis penelitian kuantitatif dengan deskriptif analitik yang menggunakan metode crosssectonal. Metode ini mengobservasi variabel bebas dan variabel terikat pada waktu yang bersamaan (Notoatmodjo, 2018). Penelitian dilakukan di Laboratorium Patologi Klinik RSUD DR. H. Abdul Moeloek Provinsi Lampung. Waktu penelitian dilakukan pada bulan Februari 2021. Jumlah sampel penelitian sebanyak 35 pasien dengan menggunakan metode total sampling.

Kriteria pengambilan sampe terdiri dari kriteria inklusi yaitu pasien yang telah terdiagnosa infeksi dengue primer dan sekunder dengan alat hematology analyzer, pasien infeksi dengue yang telah dilakukan pemeriksaan darah rutin dan pasien yang telah melakukan pemeriksaan IgG dan IgM. Kriteria eklusi yaitu pasien yang memiliki riwayat penyakit kelainan darah seperti thalassemia, anemia, SLE dan ITP, dan pasien dengan penyakit infeksi lainnya seperti demam tifoid dan demam malaria. Pengolahan dan data analisis dengan menggunakan software komputer dan SPSS, dilakukan uji univariat dan uji bivariat menggunakan uji independent $T$ test dan uji Mann Whitney.

\section{HASIL DAN PEMBAHASAN}

Tabel 1 Karakteristik Responden Berdasarkan Jenis Kelamin

\begin{tabular}{ccccc}
\hline Jenis Kelamin & Primer & Sekunder & \multicolumn{2}{c}{ Total } \\
& $\mathbf{N}$ & $\mathbf{N}$ & $\mathbf{N}$ & \% \\
\hline Laki-Laki & 10 & 15 & 25 & 71,4 \\
Perempuan & 3 & 7 & 10 & 28,6 \\
\hline
\end{tabular}

Pada tabel 1 dapat dilihat dari total 35 orang yang terinfeksi dengue dimana sebanyak
71,4\% berjenis kelamin laki-laki dan 28,6\% berjenis kelamin perempuan.

Tabel 4.2 Karakteristik Responden Berdasarkan Usia

\begin{tabular}{ccccc}
\hline Usia & Primer & Sekunder & \multicolumn{2}{c}{ Total } \\
\hline $0-11$ tahun & $\mathbf{N}$ & $\mathbf{N}$ & $\mathbf{N}$ & $\mathbf{\%}$ \\
$12-25$ tahun & 4 & 1 & 5 & 14,3 \\
$26-45$ tahun & 0 & 1 & 1 & 2,9 \\
$46-65$ tahun & 4 & 8 & 12 & 34,3 \\
$>65$ tahun & 3 & 10 & 13 & 37,1 \\
& 2 & 2 & 4 & 11,4 \\
\hline
\end{tabular}

Pada tabel 4.2 dapat dilihat bahwa interval usia 0-11 tahun sebanyak 4 orang terinfeksi dengue primer dan 1 orang terinfeksi dengue sekunder (14,3\%), interval usia 12-25 tahun sebanyak 1 orang terinfeksi dengue sekunder (2,9\%), interval usia 26-45 tahun sebanyak 4 orang terinfeksi dengue primer dan 8 orang terinfeksi dengue sekunder (34,3\%), interval usia 46-65 tahun sebanyak 3 orang terinfeksi dengue primer dan 10 orang terinfeksi dengue sekunder $(37,1 \%)$ dan usia $>65$ tahun sebanyak 2 orang terinfeksi dengue primer dan 2 orang terinfeksi dengue sekunder $(11,4 \%)$.

Tabel 4.3 Karakteristik Responden Berdasarkan Jenis Infeksi Dengue

\begin{tabular}{ccc}
\hline Infeksi Dengue & $\mathbf{N}$ & $\mathbf{\%}$ \\
\hline Infeksi Dengue Primer & 13 & 37,1 \\
Infeksi Dengue Sekunder & 22 & 62,9 \\
\hline Total & $\mathbf{3 5}$ & $\mathbf{1 0 0}$
\end{tabular}

Pada tabel 4.3 terlihat bahwa pasien yang mengalami infeksi dengue primer yaitu sebanyak 13 orang $(37,1 \%)$ dan yang mengalami infeksi dengue sekunder sebanyak 22 orang $(62,9 \%)$. 
Tabel 4.4 Karakteristik Responden Berdasarkan Indeks Trombosit

\begin{tabular}{|c|c|c|c|c|c|c|}
\hline Nilai & Kategori & $\mathbf{N}$ & $\%$ & Mean & Median & (Min-Max) \\
\hline \multicolumn{7}{|c|}{ Infeksi Dengue Primer } \\
\hline \multirow{2}{*}{$\begin{array}{c}\text { PDW } \\
\text { (fL) }\end{array}$} & Rendah & 8 & 61,5 & \multirow{2}{*}{10,13} & \multirow{2}{*}{9,7} & \multirow{2}{*}{$(8,5-12,6)$} \\
\hline & Normal & 5 & 38,5 & & & \\
\hline \multirow{2}{*}{$\begin{array}{c}\text { MPV } \\
\text { (fL) }\end{array}$} & Normal & 12 & 92,3 & \multirow{2}{*}{10,35} & \multirow{2}{*}{9,7} & \multirow{2}{*}{$(8,6-17,5)$} \\
\hline & Tinggi & 1 & 2,9 & & & \\
\hline \multirow{3}{*}{$\begin{array}{c}\text { P-LCR } \\
(\%)\end{array}$} & Normal & 1 & 7,7 & \multirow{2}{*}{20,6} & \multirow{2}{*}{19,6} & \multirow{2}{*}{$(0,4-31,5)$} \\
\hline & Tinggi & 12 & 92,3 & & & \\
\hline & Rendah & 11 & 84,6 & \multirow{3}{*}{0,47} & \multirow{3}{*}{0,17} & \multirow{3}{*}{$(0,13-4,03)$} \\
\hline \multirow{2}{*}{$\begin{array}{c}\text { PCT } \\
(\%)\end{array}$} & Normal & 1 & 7,7 & & & \\
\hline & Tinggi & 1 & 7,7 & & & \\
\hline \multicolumn{7}{|c|}{ Infeksi Dengue Sekunder } \\
\hline \multirow{2}{*}{$\begin{array}{c}\text { PDW } \\
\text { (fL) }\end{array}$} & Rendah & 8 & 36,4 & \multirow{2}{*}{11,19} & \multirow{2}{*}{10,75} & \multirow{2}{*}{$(8,4-15,4)$} \\
\hline & Normal & 14 & 63,6 & & & \\
\hline $\begin{array}{l}\text { MPV } \\
\text { (fL) }\end{array}$ & Normal & 22 & 100 & 10,11 & 9,8 & $(9-11,8)$ \\
\hline P-LCR & Normal & 6 & 27,3 & 25,33 & 22,7 & $(16,3-39,6)$ \\
\hline $\begin{array}{l}(\%) \\
\text { PCT }\end{array}$ & Tinggi & 16 & $\begin{array}{l}72,7 \\
81,8\end{array}$ & & & \\
\hline$(\%)$ & Tinggi & $\begin{array}{c}10 \\
4\end{array}$ & $\begin{array}{l}01,0 \\
18,2\end{array}$ & 0,17 & 0,18 & $(0,01-0,3)$ \\
\hline
\end{tabular}

Pada tabel 4.4 terlihat bahwa pada infeksi dengue primer, nilai PDW dengan kategori rendah sebanyak 8 orang $(61,5 \%)$ dan kategori normal sebanyak 5 orang $(38,5 \%)$ dengan nilai mean 10,13 fL median 9,7 fL dan min-max 8,5-12,6 fL. Nilai MPV kategori normal sebanyak 12 orang $(92,3 \%)$ dan kategori tinggi sebanyak 1 orang $(2,9 \%)$ dengan nilai mean 10,35 fL median 9,7 fL dan min-max 8,6-17,5 fL. Nilai P-LCR dengan kategori normal sebanyak 1 orang $(7,7 \%)$ dan kategori tinggi sebanyak 12 orang $(92,3 \%)$ dengan nilai mean 20,6 fL median 19,6 fL dan min-max 0,4-31,5 fL. Nilai PCT dengan kategori rendah sebanyak 11 orang $(84,6 \%)$, kategori normal sebanyak 1 orang $(7,7 \%)$ dan kategori tinggi sebanyak 1 orang $(7,7 \%)$ dengan nilai mean 20,6\% median 19,6\% dan min-max 0,4-31,5\%.
Sedangkan pada infeksi dengue sekunder, nilai PDW dengan kategori rendah sebanyak 8 orang (36,4\%), kategori normal sebanyak 14 orang $(63,6 \%)$ nilai mean 11,19 fL median 10,75 fL dan min-max 8,4-15,4 fL. Nilai MPV dengan kategori normal sebanyak 22 orang (100\%) dengan nilai mean 10,11 fL median 9,8 fL dan min-max 9-11,8 fL. Nilai P-LCR dengan kategori normal sebanyak 6 orang $(27,3 \%)$ dan kategori tinggi sebanyak 16 orang $(72,7 \%)$ dengan nilai mean 25,33 fL median 22,7 fL dan min-max 16,3-39,6 fL. Nilai PCT dengan kategori rendah sebanyak 18 orang $(81,8 \%)$ dan kategori tinggi sebanyak 4 orang $(18,2 \%)$ dengan nilai mean $0,17 \%$ median $0,18 \%$ dan min-max 0,01-0,3\%.

Tabel 4.5 Karakteristik Responden Berdasarkan Jumlah Trombosit

\begin{tabular}{|c|c|c|c|c|c|c|}
\hline Nilai & Kategori & $\mathbf{N}$ & $\%$ & Mean & Median & (Min-Max) \\
\hline \multicolumn{7}{|c|}{ Infeksi Dengue Primer } \\
\hline Jumlah & Rendah & 5 & 38,5 & & & \\
\hline $\begin{array}{l}\text { Trombosit } \\
(\mu L)\end{array}$ & Normal & 8 & 61,5 & $169.523,08$ & 169.000 & $(46.800-258.000)$ \\
\hline \multicolumn{7}{|c|}{ Infeksi Dengue Sekunder } \\
\hline Jumlah & Rendah & 7 & 31,8 & & & \\
\hline $\begin{array}{l}\text { Trombosit } \\
(\mu L)\end{array}$ & Normal & 15 & 68,2 & $179.318,18$ & 192.000 & $(13.000-325.000)$ \\
\hline
\end{tabular}


Pada tabel 4.5 terlihat bahwa jumlah trombosit pada pasien infeksi dengue primer dengan kategori rendah sebanyak 5 orang $(38,5 \%)$ dan kategori normal sebanyak 8 orang $(61,5 \%)$ dengan nilai mean

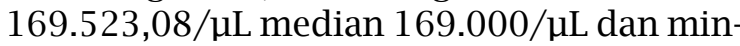
max 46.800-258.000/uL. Sedangkan jumlah trombosit pada pasien infeksi dengue sekunder dengan kategori rendah sebanyak 7 orang $(31,8 \%)$ dan kategori normal sebanyak 15 orang $(68,2 \%)$ dengan nilai mean $179.318,18 / \mu \mathrm{L}$ median $192.000 / \mu \mathrm{L}$ dan min-max 13.000-325.000/ $\mathrm{LL}$
Analisis bivariat dilakukan untuk mengetahui apakah ada perbedaan yang signifikan antar variabel independen dan variabel dependen. Dalam hal ini untuk mengetahui apakah ada perbedaan antara indeks trombosit dan jumlah trombosit pada pasien infeksi dengue primer dan sekunder di RSUD Dr. H. Abdul Moeloek Provinsi Lampung. Uji statistik yang akan digunakan yaitu uji independent $T$ test jika data terdistribusi secara normal dan uji Mann Whitney jika data tidak terdistribusi secara normal.

Tabel 4.6 Perbedaan Nilai PDW pada Pasien Infeksi Dengue Primer dan Sekunder dengan Uji Mann Whitne

\begin{tabular}{lccc}
\hline \multicolumn{1}{c}{ PDW (fL) } & N & Median \pm SD & p value \\
\hline Infeksi dengue primer & 13 & $9,7 \pm 1,2393$ & 0,068 \\
Infeksi dengue sekunder & 22 & $10,75 \pm 1,8713$ & \\
\hline
\end{tabular}

Berdasarkan tabel 4.6 bahwa nilai median PDW dengan standar deviasi pada infeksi dengue primer yaitu 9,7 $\pm 1,2393 \mathrm{fL}$ dan infeksi dengue sekunder yaitu $10,75 \pm 1,8713 f$ L. Hasil uji statistik nilai PDW pada pasien infeksi dengue primer dan sekunder didapatkan nilai $\mathrm{p}$ value $=0,068$ $(\mathrm{p}>0,05)$ dimana secara statistik tidak terdapat perbedaan antara nilai PDW pada pasien infeksi dengue primer dan sekunder.

Tabel 4.7 Perbedaan Nilai MPV pada Pasien Infeksi Dengue Primer dan Sekunder dengan Uji Mann Whitney

\begin{tabular}{lccc}
\hline \multicolumn{1}{c}{ MPV (fL) } & N & Median \pm SD & p value \\
\hline Infeksi dengue primer & 13 & $9,7 \pm 2,2508$ & 0,538 \\
Infeksi dengue sekunder & 22 & $10,087 \pm 0,8382$ & 0,538 \\
\hline
\end{tabular}

Berdasarkan tabel 4.7 bahwa nilai median MPV dengan standar deviasi pada infeksi dengue primer yaitu $9,7 \pm 2,2508 \mathrm{fL}$ dan infeksi dengue sekunder yaitu $10,087 \pm 0,8382 f L$. Hasil uji statistik nilai MPV pada pasien infeksi dengue primer dan sekunder didapatkan nilai $\mathrm{p}$ value $=0,538$ $(\mathrm{p}>0,05)$ dimana secara statistik tidak terdapat perbedaan antara nilai MPV pada pasien infeksi dengue primer dan sekunder.

Tabel 4.8 Perbedaan Nilai P-LCR pada Pasien Infeksi Dengue Primer dan Sekunder dengan Uji Independent T Test

\begin{tabular}{llcc}
\multicolumn{1}{c}{ P-LCR (\%) } & N & Mean \pm SD & p value \\
\hline Infeksi dengue primer & 13 & $20,58 \pm 7,9355$ & 0,101 \\
Infeksi dengue sekunder & 22 & $25,33 \pm 6,8380$ & 0 \\
\hline
\end{tabular}

Berdasarkan tabel 4.8 bahwa nilai mean PLCR dengan standar deviasi pada infeksi dengue primer yaitu 20,58 $7,9355 \%$ dan infeksi dengue sekunder yaitu $25,33 \pm 6,8380 \%$. Hasil uji statistik nilai P-LCR pada pasien infeksi dengue primer dan sekunder didapatkan nilai $\mathrm{p}$ value $=0,101$ $(\mathrm{p}>0,05)$ dimana secara statistik tidak terdapat perbedaan antara nilai P-LCR pada pasien infeksi dengue primer dan sekunder. 
Tabel 4.9 Perbedaan Nilai PCT pada Pasien Infeksi Dengue Primer dan Sekunder dengan Uji Mann Whitney

\begin{tabular}{lccc}
\hline \multicolumn{1}{c}{ PCT (\%) } & N & Median \pm SD & p value \\
\hline Infeksi dengue primer & 13 & $0,17 \pm 1,06995$ & \multirow{2}{*}{0,973} \\
Infeksi dengue sekunder & 22 & $0,18 \pm 0,07257$ & \\
\hline
\end{tabular}

Berdasarkan tabel 4.9 bahwa nilai median PCT dengan standar deviasi pada infeksi dengue primer yaitu $0,17 \pm 1,06995 \%$ dan infeksi dengue sekunder yaitu $0,18 \pm 0,07257 \%$. Hasil uji statistik nilai PCT pada pasien infeksi dengue primer dan sekunder didapatkan nilai $\mathrm{p}$ value $=0,973$ $(\mathrm{p}>0,05)$ dimana secara statistik tidak terdapat perbedaan antara nilai PCT pada pasien infeksi dengue primer dan sekunder.

Tabel 4.10 Perbedaan Jumlah Trombosit pada Pasien Infeksi Dengue Primer dan Sekunder dengan Uji Independent T Test

\begin{tabular}{llcc}
\hline \multicolumn{1}{c}{ Jumlah Trombosit $(\boldsymbol{\mu L})$} & $\mathbf{N}$ & Mean \pm SD & p value \\
\hline Infeksi dengue primer & 13 & $169.523,08 \pm 57.590,713$ & \multirow{2}{*}{0,393} \\
Infeksi dengue sekunder & 22 & $179.318,18 \pm 75.082,422$ & \\
\hline
\end{tabular}

Berdasarkan tabel 4.10 bahwa nilai mean jumlah trombosit dengan standar deviasi pada infeksi dengue primer yaitu $169.523,08 \pm 57.590,713 / \mu \mathrm{L}$ dan infeksi dengue sekunder yaitu 179.318,18 $\pm 75.082,422 / \mu \mathrm{L}$. Hasil uji statistik jumlah trombosit pada pasien infeksi dengue primer dan sekunder didapatkan nilai $\mathrm{p}$ value $=0,393(\mathrm{p}>0,05)$ dimana secara statistik tidak terdapat perbedaan antara jumlah trombosit pada pasien infeksi dengue primer dan sekunder.

\section{PEMBAHASAN}

\section{Karakteristik Responden Berdasarkan Jenis Kelamin}

Pada tabel 4.1 dapat dilihat dari 35 pasien infeksi dengue primer maupun sekunder sebagian besar $71,4 \%$ berjenis kelamin laki-laki. Hal ini dikarenakan laki-laki bekerja pada pagi hari dan pulang sore hari. Sedangkan perempuan biasanya bekerja sebagai ibu rumah tangga. Selain itu perempuan lebih sering memakai pakaian panjang dibandingkan laki-laki sehingga nyamuk tidak bisa menggigit bagian tersebut karena tertutupi oleh pakaian yang panjang. Rendahnya presentase pasien perempuan dibandingkan pasien laki-laki dikarenakan produksi sitokin anti inflamasi lebih banyak sehingga perempuan yang terinfeksi demam berdarah dengue memberikan keluhan klinis yang kurang jelas dan jarang dirawat di Rumah Sakit.

Berdasarkan karakteristik jenis kelamin didapatkan bahwa jenis kelamin laki-laki lebih banyak daripada perempuan serupa dengan hasil penelitian yang menyebutkan bahwa pasien laki-laki lebih banyak dibandingkan dengan perempuan seperti yang dilaporkan oleh Rasyada et al tahun 2014 di RSUP DR. M. Djamil padang, jumlah kasus laki-laki lebih banyak daripada perempuan dengan perbandingan 1,6:1 didapatkan bahwa jenis kelamin terbanyak adalah Laki-laki sebanyak 52 dan perempuan sebanyak 42 orang.Dari data tersebut menunjukkan bahwa laki-laki lebih rentan terhadap infeksi virus dengue terkait aktivitas, perjalanan atau pekerjaan diluar rumah saat siang hari yang merupakan waktu paparan terhadap vektor virus dengue (Saraswati dan Mulyantari, 2017).Paparan vektor pada pria lebih tinggi pada siang hari dan lebih sedikit pada wanita karena alasan sosial yaitu dikarenakan wanita mengenakan jilbab (Daaakeek et al, 2017).

\section{Karakteristik Responden Berdasarkan Usia \\ Berdasarkan tabel 4.2 dapat dilihat} bahwa interval usia terbanyak pasien infeksi dengue primer dan sekunder dalah 46-65 tahun sebanyak 37,1\%. Hal ini terjadi karena kelompok usia tersebut masih termasuk dalam kelompok usia produktif yang mana pada kelompok usia tersebut masih bekerja atau berkegiatan di luar rumah untuk memenuhi kebutuhan ekonomi. Sehingga pada penelitian ini pasien terbanyak pada kelompok usia 46- 
65 tahun. Kelompok usia pada anak yang sering terjadi pada kelompok usia yaitu 13 tahun (Nisa et al, 2012). Penelitian Saraswati tahun 2017 di Denpasar melaporkan kelompok usia terbanyak pada pasien infeksi dengue primer adalah 6-11 tahun sedangkan infeksi dengue sekunder adalah kelompok usia 26-45 tahun (Saraswati dan Mulyantara, 2017).Kelompok usia 19-45 tahun mempunyai aktivitas yang padat dan lebih banyak di luar ruangan sehingga memberikan kemungkinan lebih banyak terkena nyamuk yang terinfeksi, selain itu kurangnya kewaspadaan diri dalam perlindungan gigitan nyamuk (Vebriani et al, 2016)

\section{Karakteristik Responden Berdasarkan Jenis Infeksi Dengue}

Berdasarkan Tabel 4.3 terlihat bahwa mayoritas pasien infeksi dengue yaitu pasien dengan infeksi dengue sekunder sebanyak 62,9\%. Hal ini terjadi karena serotipe virus dengue yang masuk pada infeksi dengue sekunder berbeda dengan infeksi dengue primer. Sehingga terjadinya secondary heterologous infection dan antibody dependent enhancement (ADE).

Teori ADE menjelaskan bahwa jika terdapat salah satu antibodi spesifik terhadap serotipe virus tertentu maka akan mencegah penyakit tersebut masuk. Namun jika serotipe virus yang masuk berbeda maka antibodi tidak dapat menetralisir virus baru. Hal ini menimbulkan penyakit yang lebih berat dibandingkan sebelumnya.

Hasil penelitian ini serupa dengan penelitian Arifa et al tahun 2020 di RSUD Ulin Banjarmasin yang melaporkan bahwa demam berdarah dengue sekunder lebih banyak dibandingkan demam berdarah dengue primer (Arifa et al, 2020). Sama halnya dengan hasil penelitian Saraswati tahun 2017 di Denpasar melakukan pemeriksaan serologis terhadap pasien demam berdarah dengue didapatkan hasil sebanyak $87,17 \%$ mengalami infeksi dengue sekunder(Saraswati dan Mulyantara, 2017).

Pada infeksi dengue primer ditandai dengan IgM rendah dan muncul pertama kali sedangkan IgG diproduksi setelah 2 minggu terkena infeksi. Infeksi dengue sekunder ditandai dengan IgG yang meningkat sejak awal sekitar 2 hari setelah onset demam dan dapat bertahan lama sedangkan IgM dapat ditemukan rendah atau bahkan tidak terdeteksi (May Tanzilia, 2017).

\section{Karakteristik Responden Berdasarkan Indeks Trombosit}

Berdasarkan hasil tabel 4.4 terlihat bahwa nilai PDW pada pasien infeksi dengue primer sebagian besar masuk dalam kategori rendah sebanyak 8 orang $(61,5 \%)$ sedangkan pada infeksi dengue sekunder sebagian besar termasuk dalam katergori normal sebanyak 14 orang $(63,6 \%)$. Hal ini terjadi karena belum terjadinya proses trombopoiesis dalam tubuh pasien. Proses tromboiesis ini sangat berguna sebagai tanda dari keadaan trombositopenia. Hal ini menyebabkan sumsum tulang mengeluarkan megakariosit muda yang lebih besar sebagai kompensasi dari trombositopenia sehingga terjadi variasi ukuran diameter trombosit (Vagdatli, 2010).

Nilai MPV yang terlihat dalam tabel 4.4 bahwa pada infeksi dengue primer maupun sekunder sebagian besar termasuk dalam kategori normal sebanyak 12 orang $(92,3 \%)$ dan 22 orang (100\%). Hal ini terjadi karena belum adanya peningkatan jumlah dari trombosit sehingga nilai MPV pada hasil penelitian sebagian besar normal. Peningkatan jumlah trombosit sangat berkaitan dengan peningkatan nilai MPV.

Peningkatan nilai MPV mencerminkan terjadinya peningkatan dari jumlah trombosit yang diproduksi (Utami, 2017). Nilai P-LCR pada infeksi dengue primer maupun sekunder yang terdapat pada tabel 4.4 bahwa sebagian besar termasuk dalam kategori tinggi sebanyak 12 orang $(92,3 \%)$ dan 16 orang $(72,7 \%)$. Hal ini terjadi karena nilai P-LCR merupakan salah satu penanda aktivasi trombosit yang akan meningkat pada keadaan trombositopenia. Sehingga penelitian ini nilai P-LCR sebagian besar dalam kategori tinggi. Hasil penelitian ini sesuai dengan teori yang menjelaskan bahwa nilai P-LCR akan berbanding terbalik dengan jumlah trombosit (Lorenza, 2018).

Nilai PCT pada infeksi dengue primer maupun sekunder yang tertulis pada tabel 4.4 bahwa sebagian besar termasuk dalam kategori rendah sebanyak 11 orang $(84,6 \%)$ dan 18 orang $(81,8 \%)$. Hal ini terjadi karena pasien sedang dalam keadaan trombositopenia sehingga nilai PCT dalam penelitian cenderung banyak yang rendah. Nilai PCT sangat berpengaruh dengan tanda kondisi perburukan pasien.Hasil penelitian sesuai dengan teori yang dijelaskan bahwa 
nilai PCT dipengaruhi oleh jumlah trombosit. Pada pasien infeksi dengue nilai PCT dan jumlah trombosit cenderung menurun (Prameswari et al., 2018).

\section{Karakteristik Responden Berdasarkan Jumlah Trombosit}

Berdasarkan hasil dari tabel 4.5 terlihat bahwa sebagian besar jumlah trombosit pada infeksi dengue primer maupun sekunder termasuk dalam kategori normal sebanyak 8 orang $(61,5 \%)$ dan 15 orang (68,2\%). Hal ini terjadi karena subjek penelitian sudah memasuki fase pemulihan dimana rata-rata jumlah trombosit sudah termasuk dalam kategori normal. Pada infeksi dengue biasanya pasien mengalami penurunan jumlah trombosit (trombositopenia). Trombositopenia merupakan salah satu indikator klinis dari infeksi dengue. Mekanisme terjadinya trombositopenia dapat terjadi dikarenakan supresi sumsum tulang dan peningkatan destruksi trombosit.

Trombositopenia pada hari ke-4 merupakan titik terendah pada fase syok. Pasien demam berdarah dengue tanpa syok akan mengalami penurunan jumlah trombosit pada hari ke-3 sampai hari ke-7 tampak ringan sampai sedang namun akan kembali normal pada hari ke- 8 atau hari ke9. Peningkatan jumlah trombosit merupakan tanda dari proses penyembuhan (Puspita, 2017).

\section{Perbedaan Nilai PDW pada Pasien Infeksi Dengue Primer dan Sekunder}

Berdasarkan hasil analisis statistik uji Mann Whitney nilai $\mathrm{p}=0,068(\mathrm{p}>0,05)$ dimana hasil tersebut menunjukkan tidak terdapat perbedaan yang signifikan antara nilai PDW pada infeksi dengue primer dengan infeksi dengue sekunder. Hal ini terjadi karena nilai PDW yang mana merupakan ukuran diameter trombosit tidak terpengaruh oleh jenis infeksi primer maupun sekunder. Hasil dari penelitian ini sejalan dengan penelitian Ayu tahun 2016 di Makassar yang menyebutkan bahwa pada hari ke-5 setelah perawatan nilai PDW antara infeksi dengue primer dan sekunder tidak bermakna secara statistik.

Perbedaan Nilai MPV pada Pasien Infeksi Dengue Primer dan Sekunder

Berdasarkan hasil analisis statistik uji Mann Whitney nilai $\mathrm{p}=0,538(\mathrm{p}>0,05)$ dimana hasil tersebut menunjukkan tidak terdapat perbedaan yang signifikan antara nilai MPV pada infeksi dengue primer dengan infeksi dengue sekunder. Hal ini terjadi karena nilai MPV tidak dipengaruhi oleh jenis infeksi akan tetapi nilai MPV dipengaruhi oleh jumlah trombosit. Hasil penelitian ini sejalan dengan penelitian Ayu tahun 2016 di Makassar yang melaporkan bahwa pada hari ke-1-2, hari 2-3, hari 3-4 dan hari 4-5 perawatan nilai MPV pada infeksi dengue primer dan sekunder tidak berbeda secara bermakna. Penelitian ini juga menjelaskan bahwa nilai MPV pada infeksi dengue primer lebih rendah dibandingkan infeksi dengue sekunder.

\section{Perbedaan Nilai P-LCR pada Pasien Infeksi Dengue Primer dan Sekunder}

Berdasarkan hasil analisis statistik uji independent $T$ Test nilai $\mathrm{p}=0,101(\mathrm{p}>0,05)$ dimana hasil tersebut menunjukkan tidak terdapat perbedaan yang signifikan antara jumlah trombosit pada infeksi dengue primer dengan infeksi dengue sekunder. Hal ini dikarenakan nilai P-LCR memang berpengaruh terhadap demam dengue dan demam berdarah dengue tetapi tidak dipengaruhi oleh jenis infeksi dengue. Nilai P-LCR akan lebih tinggi pada demam berdarah dengue dibandingkan demam dengue. Nilai P-LCR yang meningkat menentukan trombositopenia dan jika menurun menentukan trombositosis (Lorenza, 2018).

\section{Perbedaan Nilai PCT pada Pasien Infeksi Dengue Primer dan Sekunder}

Berdasarkan hasil analisis statistik uji Mann Whitney nilai $\mathrm{p}=0,973(\mathrm{p}>0,05)$ dimana hasil tersebut menunjukkan tidak terdapat perbedaan yang signifikan antara nilai PCT pada infeksi dengue primer dengan infeksi dengue sekunder. Hal ini terjadi dikarenakan nilai PCT tidak dipengaruhi oleh jenis infeksi melainkan dipengaruhi oleh jumlah trombosit. Nilai PCT yang mengalami peningkatan $>0,01$ memiliki resiko terjadi dengue shock syndrom dan nilai $\mathrm{PCT}<0,14$ lebih sensitif sebagai prediktor syok di demam dengue (Prameswari et al., 2018).

Perbedaan Jumlah Trombosit pada Pasien Infeksi Dengue Primer dan Sekunder

Berdasarkan hasil analisis statistik uji independent $T$ Test nilai $\mathrm{p}=0,393(\mathrm{p}>0,05)$ dimana hasil tersebut menunjukkan tidak 
terdapat perbedaan yang signifikan antara jumlah trombosit pada infeksi dengue primer dengan infeksi dengue sekunder. Hal ini terjadi karena jumlah trombosit tidak terpengaruh oleh jenis infeksi. Jenis infeksi hanya dipengaruhi oleh serotipe virus yang masuk dan onset. Nilai rerata jumlah trombosit dalam penelitian ini lebih tinggi pada infeksi dengue sekunder yaitu 179.318,18/ $\mathrm{LL}$. Hal ini diduga karena jumlah data penelitian yang tidak seimbang antara infeksi dengue primer dan sekunder sehingga menghasilkan perbedaan hasil uji statistik dan rerata jumlah trombosit. Biasanya jumlah trombosit pada pasien infeksi dengue sekunder lebih rendah dikarenakan manifestasi klinisnya lebih berat bahkan sampai terjadi dengue syok sindrom. Selain itu, jumlah trombosit pada penelitian ini mayoritas sudah memasuki masa perbaikan jumlah trombosit sehingga mayoritas jumlah trombositnya normal.

Hasil penelitian ini tidak sesuai dengan penelitian Arifa tahun 2020 di Banjarmasin yang menjelaskan bahwa rerata jumlah trombosit pada kelompok DBD primer sebesar 160.000/uL lebih tinggi dibandingkan kelompok DBD sekunder

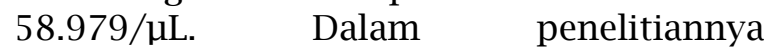
menyebutkan bahwa terdapat perbedaan bermakna antara rerata jumlah trombosit DBD primer dan sekunder. Namun hasil penelitian ini sejalan dengan penelitian Utari tahun 2018 di Padang menjelaskan tidak berbeda bermakna secara statistik nilai jumlah trombosit pada pasien infeksi dengue primer dan sekunder. Hasil penelitian serupa dengan penelitian Kidwai tahun 2014 di Pakistan dimana jumlah rerata trombosit pada infeksi dengue primer lebih rendah $28.000 \mathrm{sel} / \mathrm{mm}^{3}$ dibandingkan infeksi dengue sekunder $31.000 \mathrm{sel} / \mathrm{mm}^{3}$.

\section{KESIMPULAN}

Berdasarkan hasil dan pembahasan penelitian maka dapat diambil kesimpulan mengenai adanya perbandingan nilai indeks trombosit dan jumlah trombosit pada pasien infeksi dengue primer dan sekunder dengan jumlah pasien sebanyak 35 pasien infeksi dengue di RSUD DR. H. Abdul Moeloek Provinsi Lampung Tahun 2020, maka dapat diambil kesimpulan sebagian besar infeksi dengue sekunder sebanyak 22 orang (62,9\%). Sebagian besar nilai PDW dengan kategori rendah sebanyak 8 orang $(36,4 \%)$, kategori normal sebanyak 14 orang $(63,6 \%)$. frekuensi nilai MPV pada pasien infeksi dengue primer sebagian besar dengan kategori normal sebanyak 12 orang (92,3\%) dan kategori tinggi sebanyak 1 orang (2,9\%). Sedangkan nilai MPV infeksi dengue sekunder dengan kategori normal sebanyak 22 orang (100\%). Distribusi frekuensi nilai P-LCR pada pasien infeksi dengue primer sebagian besar dengan kategori kategori tinggi sebanyak 12 orang (92,3\%). Distribusi frekuensi nilai PCT pada pasien infeksi dengue primer dengan kategori rendah sebanyak 11 orang $(84,6 \%)$, Distribusi frekuensi jumlah trombosit dengan jumlah trombosit pada infeksi dengue primer dengan kategori rendah sebanyak 5 orang $(38,5 \%)$ dan kategori normal sebanyak 8 orang (61,5\%). Sedangkan pada pasien infeksi dengue sekunder dengan kategori rendah sebanyak 7 orang $(31,8 \%)$ dan kategori normal sebanyak 15 orang $(68,2 \%)$.Perbedaan nilai indeks trombosit (PDW, MPV, P-LCR, PCT) dan jumlah trombosit antara pasien infeksi dengue primer dan sekunder menunjukkan tidak terdapat perbedaan yang signifikan antara kedua variable dengan masing-masing $p$ value; $\mathrm{PDW} p$ value $=0,068(\mathrm{p}>0,05), \mathrm{MPV} p$ value $=0,538(\mathrm{p}>0,05), \mathrm{P}-\mathrm{LCR} p$ value $=0,101$ $(\mathrm{p}>0,05)$, PCT $p$ value $=0,973(\mathrm{p}>0,05)$ dan jumlah trombosit $p$ value $=0,393(\mathrm{p}>0,05)$.

\section{DAFTAR PUSTAKA}

Arifa, I. N., Hendriyono, F. X., \& Hartoyo, E. 2020. Perbedaan Jumlah Trombosit Pasien Demam Berdarah Dengue Primer dan Sekunder pada Anak. Homeostasis, 1(1), 31-38.

Astuti, D. (2020). Nilai Indeks Trombosit Sebagai Kontrol Kualitas Komponen Konsentrat Trombosit. Meditory: The Journal of Medical Laboratory, 8(2), 8594.

Ayu, P. R., Bahrun, U., \& Arif, M. (2016). Platelet Demam Berdarah Dengue. Indonesian Journal of Clinical Pathology And Medical Laboratory, 18(3), 157-160.

Babu, E., \& Basu, D. 2004. Platelet Large Cell Ratio In The Differential Diagnosis of Abnormal Platelet Counts. Indian journal of pathology \& microbiology, 47(2), 202-205.

Chatterjee, A. B., Matti, M., \& Kulkarni, V. 2020. Role of platelet parameters in dengue fever in children. Pediatr Oncall J, 17(1).

Daakeek, A. M., Alghasali, H. S., Bahashwan, A. A., 2017. Dengue Related at Ibn-Sina Hospital - Al - Mukalla : Causes and 
Alarming Signals. Journal of Infectious Diseases and Treatment. 3(2), pp. 1-7.

Kemenkes RI. 2020. Kasus DBD di Indonesia. Diunduh dari: https://www.kemkes.go.id/artic le/view/20070900004/hinggajuli-kasus-dbd-di-indonesiacapai-71-ribu.html

Kidwai AA, Riaz SU, Aatif S, Paracha S. 2014. Spontaneous platelet recovery time in primary and secondary dengue infection in a tertiary care hospital. J Pak Med Assac.64(2):4.

Lorenza, A., Arkhaesi, N., \& Hardian, H. 2018. Perbandingan Platelet Large Cell Ratio (P-Lcr) Pada Anak Dengan Demam Dengue Dan Demam Berdarah Dengue. Diponegoro Medical Journal (Jurnal Kedokteran Diponegoro), 7(2), 826-839.

Lutfiyah, I. 2017. Kejadian Penyakit Demam Berdarah Dengue Berdasarkan Hasil Pemeriksaan Imunoglobulin (Studi Di Rumah Sakit Roemani Muhammadiyah Semarang) (Doctoral dissertation, Universitas Muhammadiyah Semarang).

May Tanzilia, N. Z. 2017. Comparative Diagnostic Value of Anti-Dengue IgG, Anti-Dengue IgM of Two Rapid Tests in Dengue Virus Infection. International Journal of Pharmaceutical Research. Oct - Dec 2020. Vol 14. Issue 4. ISSN 09752366. International Journal of Pharmaceutical Research , Oct - Dec 2020. Vol 14. Issue 4. ISSN 0975-2366.

Nisa, W. D., Notoatmojo, H., \& Rohmani, A. 2012. Karakteristik Demam Berdarah Dengue Pada Anak Di Rumah Sakit Roemani Semarang. Jurnal Kedokteran Muhammadiyah, 1(3).

Noreka, A. H., Lardo, S., \& Nugrohowati, N. 2020. Hematocrit, Thrombocyte, Body Mass Index, and Their Associations with the Severity of Dengue Hemorrhagic Fever Among Adult Patients at Esnawan Antariksa Air Force Hospital, Jakarta. In 4th International Symposium on Health Research (ISHR 2019) (pp. 640643). Atlantis Press.

Notoadmojo. 2018. Metodologi Penelitian Kesehatan. Jakarta: Rineka cipta

Prameswari, A., Iskandar, A., \& Wafi, M. 2018. Jumlah Rerata Trombosit Dan Plateletcrit (MPV dan PCT) Sebagai Prediktor Syok Pada Anak Yang Terinfeksi Dengue Di Rs Dr. Saiful
Anwar Malang. Majalah Kesehatan FKUB, 5(3), 153-159.

Puspita, R. I. 2017. Hubungan Immature Platelet Fraction dengan Perubahan Hitung Trombosit Pada Pasien Demam Berdarah Penelitian Analisis Observasional Cross-Sectional Di Divisi Tropik Infeksi Rumah Sakit Umum Daerah Dr Soetomo Surabaya (Doctoral dissertation, Universitas Airlangga).

Rasyada, A., Nasrul, E., \& Edward, Z. 2014. Hubungan nilai hematokrit terhadap jumlah trombosit pada penderita demam berdarah dengue. Jurnal Kesehatan Andalas, 3(3).

Saraswati, L. P. C., \& Mulyantari, N. K. 2017. Prevalensi Demam Berdarah Dengue (DBD) Primer dan Sekunder Berdasarkan Hasil Pemeriksaan Serologis di Rumah Sakit Balimed Denpasar. E-Jurnal Medika Udayana, 6(8).

Suhendro Nainggolan, L, Chen, K, and Pohan, HT. 2014. Demam Berdarah Dengue. Dalam: Sudoyo AW, Setiyohadi B, Alwi I, et al., penyunting. Buku Ajar Ilmu Penyakit Dalam. Edisi IV. Jakarta: Internal Publishing.

Syuhada, S., \& Gunarto, G. 2015. Hubungan Antara Nilai Platelet Distribution Width (PDW) Dan Mean Platelet Volume (MPV) Terhadap Derajat Klinis Demam Berdarah Dengue (DBD) Di RSUD Dr. H. Abdoel Moeloek. Jurnal Ilmu Kedokteran dan Kesehatan, 2(2).

Utari FP, Efrida, Kadril H. 2018. Perbandingan Nilai Hematokrit dan Jumlah Trombosit antara Infeksi Dengue Primer dan Dengue Sekunder pada Anak di RSUP. Dr. M. Djamil. Jurnal Kesehatan Andalas. 7(1):118-123

Vagdatli, E., Gounari, E., Lazaridou, E., Katsibourlia, E., Tsikopoulou, F., \& Labrianou, I. 2010. Platelet distribution width: a simple, practical and specific marker of activation of coagulation. Hippokratia, 14(1), 28.

Vebriani, L., Wardana, Z., Fridayenti., 2016. Karakteristik Hematologi Pasien Demam Berdarah Dengue di Bagian Penyakit Dalam RSUD Arifin Achmad Provinsi Riau Periode 1 Januari - 31 Desember 2013, 3(1), pp. 1-20

WHO. 2020. Dengue and Severe Dengue. Diunduh dari: https://www.who.int/news-room/factsheets/detail/dengue-and-severedengue 